\title{
Antibodies to alcohol altered liver cell determinants in patients with alcoholic liver disease
}

\author{
J NEUBERGER, I R CROSSLEY, J B SAUNDERS, M DAVIS, \\ B PORTMANN, A L W F EDDLESTON, AND ROGER WILLIAMS
}

\author{
From the Liver Unit, King's College Hospital and Medical School, Denmark Hill, London
}

SUMMARY Circulating antibodies reacting specifically with hepatocytes isolated from ethanol pretreated rabbits have been demonstrated by two techniques - induced cytotoxicity and immunofluorescence. In the cytotoxicity assay antibodies were found in seven of $19(39 \%)$ of patients with alcoholic fatty liver (with or without fibrosis), six of $13(46 \%)$ of those with alcoholic hepatitis, 15 of $36(43 \%)$ of those with cirrhosis, and seven of 14 patients $(50 \%)$ of those with hepatitis and cirrhosis. In the immunofluorescence studies, nine of 15 sera induced a granular pattern of fluorescence on the ethanol pretreated hepatocytes; two sera which induced significant cytotoxicity did not induce immunofluorescence. No ethanol related antibodies were found in normal individuals or in patients with other types of acute or chronic liver disease. These results show that antibodies directed against ethanol altered liver cell determinants are present in the serum of $43 \%$ of patients with alcoholic liver disease, and suggest a mechanism whereby chronic alcohol consumption may, by inducing antigenic changes in hepatocyte membranes, trigger a cell damaging immune reaction.

Epidemiological studies have shown that the risk of developing alcoholic cirrhosis is related to the quantity and duration of alcohol consumption, ${ }^{1}$ but there is considerable variation in individual susceptibility to the hepatotoxic effects of alcohol. ${ }^{2}$ While there is good evidence for a direct toxic effect of ethanol or its major metabolite acetaldehyde on hepatocyte function ${ }^{3}$ there is also considerable evidence that immunological mechanisms are implicated in the development of cell damage.

In patients with alcoholic hepatitis, lymphocytes have been shown to be sensitised to antigens in an homogenate of normal liver, ${ }^{4}$ to be cytotoxic to Chang cells, ${ }^{5}$ and to normal rabbit hepatocytes in culture. $^{6}$ In other studies, lymphocytes from patients with alcoholic hepatitis were shown to be sensitised to alcoholic hyaline ${ }^{7}$ and acetaldehyde, ${ }^{8}$ which suggests that additional, and more specific, immune responses directed against liver cell components altered by ethanol, or a metabolite such as acetaldehyde, may be involved in the pathogenesis of alcoholic liver disease and the progression

Address for correspondence: Dr J Neuberger, Liver Unit, King's College Hospital and Medical School, Denmark Hill, London SE5 8RX.

Received for publication 13 June 1983 to cirrhosis. The nature of these determinants remains unknown.

The involvement of host factors in determining the response to the effect of alcohol on the hepatocyte is suggested by the association between the histocompatibility antigens HLA B8 and DR3, genetic markers of several immune mediated disorders, and the more rapid development of cirrhosis, ${ }^{9}$ and an increased incidence of autoantibodies in patients with alcoholic cirrhosis. ${ }^{10}$

In the present study we have isolated hepatocytes from rabbits pretreated with ethanol, thus allowing the relevant antigen to be generated in vivo, and by means of induced cytotoxicity and immunofluorescence we have examined sera from patients with alcoholic liver damage for the presence of circulating antibodies reacting with the specific alcohol altered liver cell determinants.

\section{Methods}

\section{PATIENTS}

The 82 patients ( 56 men, 26 women; mean age 49 years, range $25-69$ years) had had a minimum daily alcohol intake of $80 \mathrm{~g}$ in the men and $40 \mathrm{~g}$ in the 
women for at least four years. Investigations showed no cause for liver damage other than chronic alcohol consumption. Liver biopsy was carried out in all patients and the biopsy appearances were classified by a consultant histopathologist (BP) into one of the following four categories: (i) fatty liver, with or without fibrosis (19 patients); (ii) alcoholic hepatitis (13); (iii) cirrhosis without a superimposed alcoholic hepatitis (36); or (iv) cirrhosis with hepatitis (14 patients). Individual histological features such as fat, central fibrosis, portal tract and lobular mononuclear cell infiltrate and Mallory's hyaline were scored semi-quantitatively on a five point scale $(0$, $1+, 2+, 3+, 4+) .{ }^{11}$ Liver biopsies, taken within one month of obtaining serum for antibody testing, were available from 61 patients, and only these biopsies were used for analysing the correlation between the individual histological features and the presence or absence of the ethanol related antibody.

Patients were questioned using a standardised and well validated interview schedule ${ }^{9}$ to establish their life time alcohol intake. Key events in the patient's life were established and these were used as anchor points to determine the evolution of the patient's drinking habits. The patient was questioned about the type and amount of alcoholic drink taken during successive periods of his life. From this, cumulative, mean and maximum daily intakes were calculated. The latter was defined as the maximum average daily intake attained for a period of at least one year. In all but 14 patients this represented the year before admission.

Controls consisted of 30 healthy laboratory personnel (16 men, ages range 22-38 years), 16 patients with acute liver disease not related to alcohol (paracetamol overdose (two), hepatic failure after halothane anaesthesia (five), carbon tetrachloride poisoning (one), rifampicin-isoniazid toxicity (four), hepatitis A viral infection (three), ampicillin hypersensitivity (one)) and eight patients with $\mathrm{HBsAg}$ negative chronic active hepatitis (14 men, ages range 16-53 years) six of whom had cirrhosis. None had a daily ethanol intake greater than $40 \mathrm{~g}$.

\section{PREPARATION OF ALCOHOL ALTERED} HEPATOCYTES

Female New Zealand white rabbits weighing 2-2.5 $\mathrm{kg}$ were given ethanol $(1 \mathrm{~g} / \mathrm{kg}$ daily $)$ by intraperitoneal injection for seven days. On the eighth day the animals were killed by injection with $300 \mathrm{mg}$ pentabarbitone and 1000 IU preservative free heparin. The livers were removed in a sterile fashion and flushed with RPMI 1640 with glutamine (Gibco) medium containing penicillin $150 \mathrm{mg} / \mathrm{l}$, streptomycin $150 \mathrm{mg} / \mathrm{l}$, and amphotericin $0.4 \mathrm{mg} / \mathrm{l}$.
PREPARATION OF SERA

Complement was inactivated in all serum samples by heating at $56^{\circ} \mathrm{C}$ for 30 minutes. To remove any antibodies reacting with normal rabbit liver cell components, $200 \mu \mathrm{l}$ serum was incubated at $4^{\circ} \mathrm{C}$ for 30 minutes with an equal volume of normal rabbit hepatocytes isolated by collagenase digestion and, after separation, the serum was incubated for a further 30 minutes at room temperature with an equal volume of normal hepatocytes. Before testing the serum with the ethanol pretreated rabbit hepatocytes, all serum samples were tested with hepatocytes isolated from untreated rabbits to ensure that these samples did not induce immunofluorescence or significant cytotoxicity to these control target cells; indicating that all antibodies reacting with normal liver cell components had been absorbed.

\section{CYTOTOXICITY ASSAY}

The liver was minced using sterile scalpels and, after three washings, the liver was incubated for four hours with $0.01 \%$ collagenase (Boehringer) in $10 \%$ fetal calf serum (Gibco) and RPMI 1640 at $37^{\circ} \mathrm{C}$ in an atmosphere of $5 \% \quad \mathrm{CO}_{2} / 95 \% \mathrm{O}_{2}$. After serial washings, isolated hepatocytes were removed and maintained in short term tissue culture for up to one week. ${ }^{12}$ Examination of these cells under electronmicroscopy showed that there was less than $2 \%$ contamination of the hepatocytes by other cells. Hepatocytes were then seeded into microcytotoxicity plates (Falcon) to give 200 cells per well. After overnight incubation at $37^{\circ} \mathrm{C}$, the cells were incubated for two hours with $10 \mu \mathrm{l}$ of test or control absorbed serum diluted 1 in 100 in RPMI 1640. This is to allow any antibody present to react with membrane determinants on the hepatocytes. All samples were tested in at least 10 wells. Lymphocytes were isolated from normal individuals using dextran sedimentation, cotton wool incubation and Ficoll-Triosil density centrifugation. ${ }^{12}$ Peroxidase staining showed that more than $95 \%$ cells were lymphocytes. The lymphocytes were then added to the washed hepatocytes to give a ratio of 100 lymphocytes to each hepatocyte to allow those lymphocytes with receptors for the $\mathrm{Fc}$ region of antibody molecules to bind to and lyse any antibody coated target cells. After incubation for $\mathbf{4 8}$ hours at $37^{\circ} \mathrm{C}$, the plates were inverted for two hours, then gently washed to remove all non-adherent cells. After fixing and staining, the remaining adherent hepatocytes were counted without knowledge of the serum, and the percentage cytotoxicity determined from the formula:

$$
\% \text { cytotoxicity }=\frac{\mathrm{NC}-\mathrm{NT}}{\mathrm{NC}} \times 100
$$


where $\mathrm{NC}=$ mean number of cells remaining in control wells and NT $=$ mean number of cells remaining in test wells.

Cytotoxicity was considered to be significantly increased when the value was more than two standard deviation above the mean of values obtained with absorbed serum from the 30 control individuals $(14+2 \times 7 \cdot 5 \%=29 \%$; mean $+2 \times \mathrm{SD})$. Values below this level were considered to be within the normal range.

INDIRECT IMMUNOFLUORESCENCE TECHNIQUES Hepatocytes from control and alcohol treated rabbits were isolated mechanically using a sterile 21 gauge needle and scalpel. Dead and clumped cells were removed by passing the cells over a nylon wool column twice. ${ }^{12}$ The cells were added to RPMI 1640 containing $10 \%$ fetal calf serum and diluted to give a concentration of three to four cells per high power field. Two hundred microlitres of the cell suspension were incubated with a similar volume of serum diluted 1 in 4 in RPMI 1640 for 30 minutes at $37^{\circ} \mathrm{C}$. The cells were washed three times and incubated for a further 30 minutes at $37^{\circ} \mathrm{C}$ with fluoroscein isothiocyanate conjugated anti-human immunoglobulin (Wellcome Reagents) diluted 1 in 10 . The cells were washed three more times and then examined under ultraviolet light using a LeitzOrthoplan microscopy with incident light fluorescence.

\section{STATISTICS}

Wilcoxon's test for paired or unpaired samples (as appropriate) was used.

\section{Results}

Significant cytotoxicity to ethanol altered hepatocytes was induced by $35(43 \%)$ of the absorbed sera from patients with alcohol associated liver disease. None of the sera from healthy controls or those with liver disease unrelated to alcohol induced significant cytotoxicity. The antibody was found in $37 \%$ of those with fatty liver, with or without fibrosis, $46 \%$ with alcoholic hepatitis, $42 \%$ with cirrhosis but no superimposed hepatitis, and $50 \%$ of those with hepatitis and cirrhosis (Table 1). The coefficient of variation was $11 \%$.

\section{SPECIFICITY OF THE ANTIBODY}

In order to show the specific involvement of antibodies rather than other serum factors in the cytotoxicity reaction, 10 sera inducing significant cytotoxicity to ethanol altered hepatocytes were used in blocking experiments. After incubation of the sera with ethanol altered hepatocytes, the cells
Table 1 Number of patients with alcoholic liver disease whose absorbed sera induced significant cytotoxicity to ethanol pretreated hepatocytes

\begin{tabular}{lll}
\hline & $\begin{array}{l}\text { Patients } \\
\text { tested } \\
(\text { no) }\end{array}$ & $\begin{array}{l}\text { Number } \\
\text { inducing } \\
\text { significant } \\
\text { cytotoxicity } \\
(\%)\end{array}$ \\
\hline Diagnosis & 19 & $7(37)$ \\
\hline Alcoholic fatty liver & 13 & $6(46)$ \\
Alcoholic hepatitis & 36 & $15(42)$ \\
$\begin{array}{l}\text { Alcoholic cirrhosis } \\
\text { Alcoholic cirrhosis }\end{array}$ & 14 & $7(50)$ \\
and hepatitis & 82 & $35(43)$ \\
\hline Total & & \\
\hline
\end{tabular}

were washed and the antibody coated target cells were incubated for a further two hours with $2 \mu \mathrm{g}$ of the $F(a b)_{2}$ fragment of antibody to the Fc portion of human immunoglobulin, to prevent the lymphocytes binding to, the lysing, the target cells. The percentage cytotoxicity fell from $42 \pm 10 \%$ to $9 \cdot 2 \pm 9 \%(\mathrm{p}<0.01$, Wilcoxon's paired rank test).

To show the antibodies were reacting with a surface determinant, the 10 sera used above were further incubated with ethanol altered hepatocytes to remove such antibodies reacting with ethanol altered liver cell membrane determinants. After absorption, none of the sera induced significant cytotoxicity to ethanol-altered cells - the percentage cytotoxicity falling from $42 \pm 10 \%$ to $6 \cdot 2 \pm 6 \%$ ( $p<0 \cdot 01$, Wilcoxon's paired rank test).

As another examination of the specificity of the reaction, six sera inducing significant cytotoxicity to ethanol altered hepatocytes were incubated with liver cells isolated from rabbits exposed to halothane $1 \%$ in $99 \%$ oxygen 18 hours before killing, a procedure that has been shown to be associated with the appearance of specific halothane altered antigenic determinants. ${ }^{13}$ None of the alcohol sera induced significant cytotoxicity to the halothane altered hepatocyte.

\section{IMMUNOFLUORESCENCE STUDIES}

Of the 15 sera examined, six from eight patients with alcoholic cirrhosis induced a granular pattern of immunofluorescence in $25-55 \%$ of the cells after incubation of the hepatocytes from ethanol pretreated rabbits (Figure). A similar granular pattern was seen in all three sera from those with alcoholic hepatitis, but in none of the four sera from patients with fatty liver. Two of the sera from patients with fatty liver induced significant cytotoxicity to ethanol pretreated hepatocytes. All the sera which induced a granular fluorescence to 


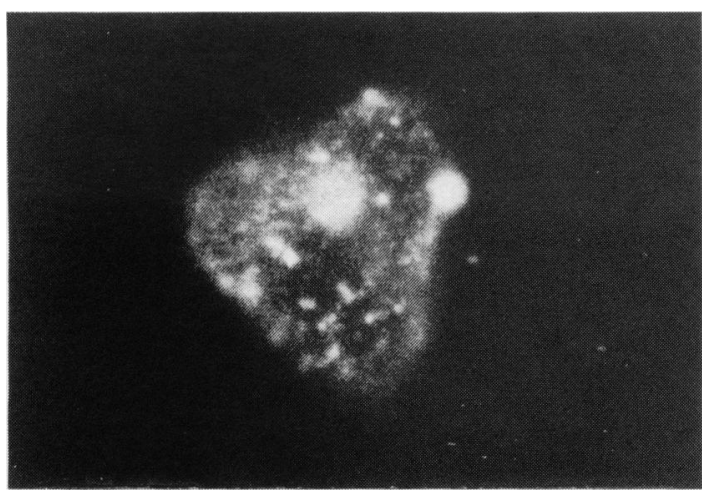

Figure Granular patterns of immunofluorescence seen on alcohol treated hepatocytes incubated with absorbed serum from a patient with alcoholic cirrhosis

ethanol pretreated hepatocytes also induced significant cytotoxicity to these hepatocytes.

CORRELATION WITH CLINICAL AND HISTOLOGICAL FINDINGS AND ALCOHOL INTAKE

There was no significant difference between the sex of patients with and without the antibody in each histological group, and there was no correlation between percentage cytotoxicity and the age of the patient, or the serum bilirubin, transaminase, or alkaline phosphatase at the time of measurement of serum antibody. The ethanol related antibodies, however, were found significantly less often in patients with moderate and severe fatty infiltration than in those with no, or minimal, fatty change (Table 2). The period of abstinence from alcohol was similar in those who did and did not have the ethanol related antibody. In contrast, there was no correlation with the degree of fibrosis, portal tract

Table 2 Relationship of the ethanol related antibody to the presence of histological features (61 biopsies examined)

\begin{tabular}{llll}
\hline $\begin{array}{l}\text { Histological feature } \\
\text { and grade }\end{array}$ & $\begin{array}{l}\text { Patients } \\
(\text { no) }\end{array}$ & $\begin{array}{l}\text { Positive } \\
\text { antibody } \\
(\%)\end{array}$ \\
\hline Fat & $0-1$ & 32 & $17(53)$ \\
Central fibrosis & $2-4$ & 29 & $9(79)^{*}$ \\
Portal tract infiltrate & $0-1$ & 26 & $12(46)$ \\
& $2-4$ & 35 & $14(40)$ \\
Lobular infiltrate & $0-1$ & 19 & $8(42)$ \\
Mallory's hyaline & $2-4$ & 42 & $18(43)$ \\
& $0-1$ & 33 & $15(45)$ \\
& $2-4$ & 28 & $11(39)$ \\
& $0-1$ & 45 & $19(42)$ \\
& $2-4$ & 16 & $7(43)$
\end{tabular}

${ }^{*} \mathrm{p}<0.05$ (Wilcoxon's rank test). and lobular mononuclear cell infiltrate or Mallory's hyaline.

There was significant correlation with the percent cytotoxicity induced by sera and the cumulative life line $(r=0.20, p<0.05)$ and maximum $(r=0.22$, $p<0.05)$ alcohol intake of these patients. Significant cytotoxicity was found more commonly in regular daily drinkers than in the 'binge' drinkers.

\section{Discussion}

These findings show that almost half the patients with alcoholic liver disease have a circulating antibody which reacts with a specific determinant present on the surface of hepatocytes isolated from rabbits pretreated with ethanol. This antibody is specific to patients with alcoholic liver injuries as it has not been found in patients with other liver disease nor in normal healthy controls. Furthermore, none of the sera tested induced significant cytotoxicity to halothane altered hepatocytes, another instance of a drug metabolite associated liver neoantigen. ${ }^{12}$ This 'ethanol related antibody' can induce normal lymphocytes to become cytotoxic to ethanol pretreated hepatocytes in vitro, and the mechanism is almost certainly one of an antibody dependent cell mediated cytotoxicity reaction (ADCC), in which the antibody specifically binds to a membrane antigen in a target cell and interacts via the Fc portion with lymphocytes bearing $F c$ receptors. The involvement of such an ADCC reaction may be shown by the blocking that occurs when the Fc portion of the antibody coating the target cell is masked by the $F(a b)_{2}$ portion of an anti Fc antibody. The antibody was absorbed out when the serum was incubated with ethanol treated hepatocytes but not with normal hepatocytes. This indicates that the antibody reacts with an antigen present on the surface of the liver cell. The results of the immunofluorescence experiments confirm that some of these patients with alcoholic liver disease have an ethanol related antibody reacting with hepatocytes from ethanol pretreated rabbits. The immunofluorescence technique seems less sensitive than cytotoxicity as some of the sera which induced significant cytotoxicity did not induce granular fluorescence. The decreased sensitivity of the immunofluorescence method has been observed elsewhere. ${ }^{12}$

Thus the antibody is distinct from those antibodies reacting with normal liver cell components, such as the liver specific lipoprotein complex which is found in the serum of patients with alcoholic hepatitis and cirrhosis. ${ }^{14}$ The generation of a new antigen determinant could arise either as a direct effect of ethanol on the hepatocyte membrane 
or as a result of an interaction between ethanol, or one of its metabolites such as acetaldehyde, with cellular macromolecules thereby altering the antigenicity of the membrane. Such a mechanism has been postulated for halothane. ${ }^{13}$

The presence of specific ethanol related antibody was recently reported ${ }^{15}$ using indirect immunofluorescence and using a leucocyte migration test to detect sensitisation to a liver homogenate from alcohol treated rabbits. ${ }^{16}$ Krogsgaard et al, ${ }^{17}$ however, were unable to confirm these findings using immunofluorescence. Part of the explanation for the difference in findings may lie in different methodological techniques.

Why these antibodies were detected in only half the patients with alcoholic liver disease remains to be established. The negative correlation with the degree of fatty change raises the possibility that some alcoholic patients are more prone to the effects of alcohol on intermediary metabolism, whereas in others a cytotoxic reaction, possibly mediated by antibody dependent cell mediated cytotoxicity, occurs preferentially. While the findings do not exclude the possibility that the presence of the alcohol specific antibody may be secondary to alcoholic liver damage, they do suggest a gradual process of steadily increasing antibody production as excessive alcohol consumption continues, and may explain progressive liver damage in some patients despite discontinuation of alcohol consumption.

Dr $\mathbf{J}$ Neuberger is a Wellcome Senior Research Fellow. The support of Ciba-Geigy, the Department of Health and Social Security, and the Brewers' Society is gratefully acknowledged. We are indebted to Dr M Mondelli for supplying the $\mathrm{F}(\mathrm{ab})_{2}$ anti Fc.

Preliminary results of this study were presented at the Autumn meeting of the British Society of Gastroenterology in 1981.

\section{References}

1 Rubin E, Lieber CS. Ethanol metabolism in liver disease. In: Popper H, Schaffner F, eds. Progress in liver disease. New York: Grune and Stratton, 1972: 549-66.

2 Galambos JT. Alcoholic hepatitis. In: Schaffner F, Sherlock S, Leevy CM, eds. The liver and its diseases.
New York: Intercontinental Medical Books, 1974: 225-67.

3 Rubin E, Cederbaum AI. Organelle pathology of alcohol-induced hepatic injury. In: Fisher MM, Rankin JG, eds. Alcohol and the liver. New York and London: Plenum Press, 1977: 167-93.

4 Mihas AA, Bull DM, Davidson CS. Cell mediated immunity to liver in patients with alcoholic hepatitis. Lancet 1975; 1: 951-6.

5 Kakumu S, Leevy CM. Lymphocyte cytotoxicity in alcoholic hepatitis. Gastroenterology 1977; 72: 594-7.

6 Cochrane AMG, Moussouros A, Thomson AD, Portmann B, Eddleston ALWF, Williams R. Lymphocyte cytotoxicity to isolated hepatocytes in alcoholic liver disease. Gastroenterology 1977; 72: 918-23.

7 Zetterman RK, Luisada-Opper A, Leevy CM. Alcoholic hepatitis. Cell mediated immune response to alcoholic hyaline. Gastroenterology 1976; 70: 382-4.

8 Actis GC, Ponzetto A, Rizzetto M, Verme G. Cell mediated immunity to acetaldehyde in alcoholic liver disease demonstrated by the leucocyte migration test. Am J Dig Dis 1978; 23: 883-6.

9 Saunders JB, Wodak AD, Haines A et al. Accelerated development of alcoholic cirrhosis in patients with HLA B8. Lancet 1982; 1: 1381-4.

10 Bailey RJ, Krasner N, Eddleston ALWF et al. Histocompatibility antigens, autoantibodies and immunoglobulins in alcoholic liver disease. $\mathrm{Br}$ Med J 1976; 2: 727-31.

11 Theodossi A, Skene A, Portmann B et al. A study of observer variation in the assessment of liver biopsies including analysis by Kappa statistics. Gastroenterology 1980; 79: 232-41.

12 Vergani D, Mieli-Vergani G, Alberti A et al. Antibodies to the surface of halothane altered rabbit hepatocytes in patients with severe halothaneassociated hepatitis. $N$ Engl J Med 1980; 303: 66-71.

13 Neuberger JM, Mieli-Vargani G, Tredger JM, Davis $\mathbf{M}$, Williams R. Oxidative metabolism of halothane in the production of altered hepatocyte membrane antigens in acute halothane induced hepatic necrosis. Gut 1981; 22: 669-72.

14 Perperas A, Tsantoulas D, Portmann B, Eddleston ALWF, Williams R. Autoimmunity to a liver membrane lipoprotein and liver damage in alcoholic liver disease. Gut 1981; 22: 149-53.

15 MacSween RNM, Anthony RS, Farquharson M. Antibodies to alcohol-altered hepatocytes in patients with alcoholic liver disease. Lancet 1980; 2: 803-4.

16 Zauli D, Lenzi M, Cometti G, Biolchini L, Biarchi FB, Pisi F. Antibodies to alcohol altered hepatocytes. Lancet 1981; 2: 1052.

17 Krogsgaard K, Tage-Jensen U, Gluud C. Liver membrane antibodies in alcoholic liver disease. Lancet 1982; 2: 1365-6. 